\section{Potential Economic Impacts from Offshore Wind in the Mid-Atlantic Region}

Offshore wind is a clean, renewable source of energy and can be an economic driver in the United States. To better understand the employment opportunities and other potential regional economic impacts from offshore wind development, the U.S. Department of Energy (DOE) funded research that focuses on four regions of the country. The studies use multiple scenarios with various local job and domestic manufacturing content assumptions. Each regional study uses the new offshore wind Jobs and Economic Development Impacts (JEDI) model, developed by the National Renewable Energy Laboratory. This fact sheet summarizes the potential economic impacts for the Mid-Atlantic region.

\section{JEDI Models}

The JEDI models are spreadsheet-based tools that estimate the economic impacts of constructing and operating power plants, fuel-production facilities, and other projects at the local level. JEDI results are intended to be estimates, not precise predictions. Based on user-entered project-specific data or default inputs (derived from industry norms), the JEDI models estimate the number of jobs and other economic impacts to an area (in this case, the Mid-Atlantic region) that can reasonably be supported by a new power plant, like an offshore wind facility. The JEDI models estimate gross impacts and are not a measure of project profitability or viability. Jobs, earnings, and regional economic output are distributed across three categories:

- Project Development and Onsite Labor Impacts

- Local Revenue and Supply Chain Impacts

- Induced Impacts.

Economic multipliers contained within the model are derived from IMPLAN Group's IMpact analysis for PLANning

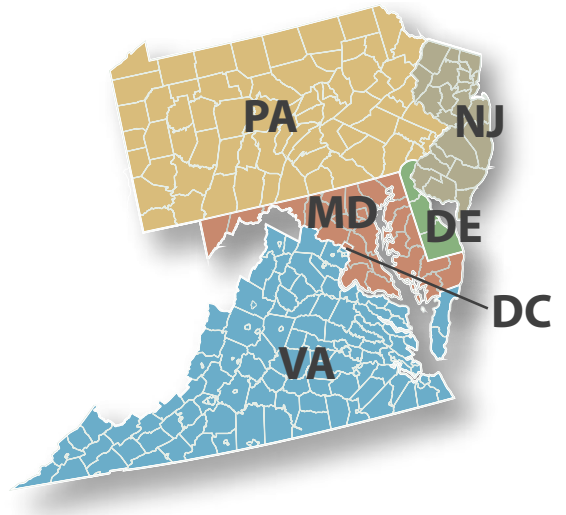

Figure 1. States included in the Mid-Atlantic region. Illustration from iStock 9795506

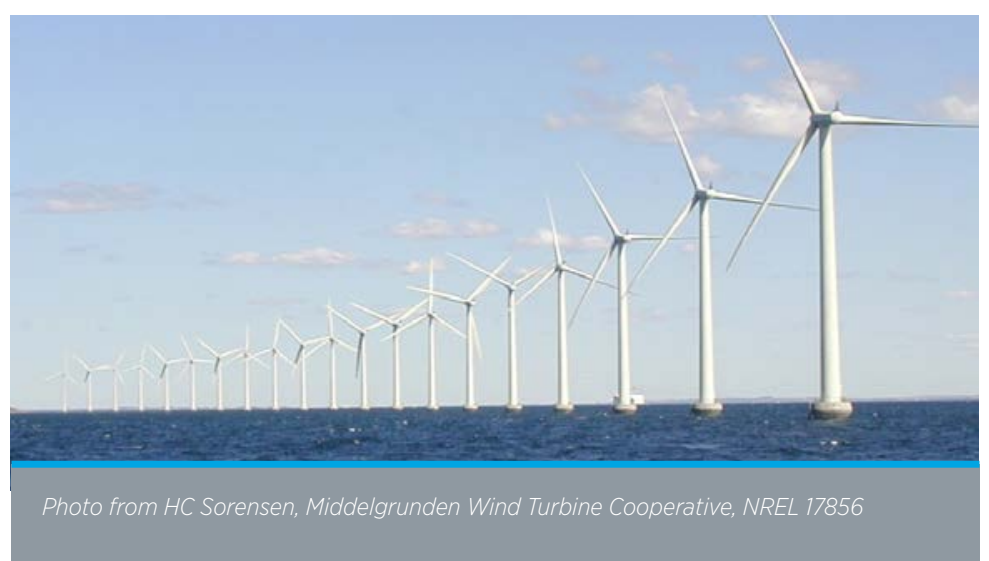

(IMPLAN) accounting software and state data files. Sources include the Bureau of Labor Statistics, Bureau of Economic Analysis, and the U.S. Census.

Jobs are measured and reported as full-time equivalents (FTEs). One FTE represents one full-time worker who is employed for one year. Part-time and seasonal workers are a fraction of an FTE. The results of each offshore wind power scenario represent an estimate of the number of supply chain, construction and operations-period jobs that could be supported in the MidAtlantic region (Figure 1).

\section{The Mid-Atlantic Region}

The Mid-Atlantic region is defined in this analysis as all U.S. coastal states from Virginia to New Jersey. Washington, D.C. is also included in the region, but deployment is only considered off of the coasts of New Jersey, Pennsylvania, Delaware, Maryland, and Virginia.

This study considered three offshore wind development scenarios examining different levels of capacity installed, regional labor force and supply chain development, and construction/operation costs. Offshore wind installations range from a low of 370 megawatts (MW) by 2020 to a high of 16,800 MW by 2030 (Table 1, on the back page).

Offshore wind installations require many specialized components that are not currently produced in the Mid-Atlantic region. Investment in manufacturing and other important offshore wind supply chain industries would be necessary for local production, which in turn would increase regional economic output. Growth of a supply chain could be correlated with deployment and local offshore wind supply chain growth could put downward pressure on costs due to economies of scale and transportation costs.

${ }^{1}$ Hamilton, B. 2013. "U.S. Offshore Wind Manufacturing and Supply Chain Development”. DE-EEO005364. Navigant Consulting, Inc. 
Table 1. Scenarios Modeled (2020 Value / 2030 Value) for Offshore Wind in the Mid-Atlantic Region (Rounded)

\begin{tabular}{|l|l|l|l|}
\multicolumn{5}{|c|}{$\mathbf{2 0 2 0 / 2 0 3 0}$} \\
\hline $\begin{array}{l}\text { Deployment } \\
\text { Scenario }\end{array}$ & $\begin{array}{l}\text { Cumulative } \\
\text { Capacity } \\
\text { Installed (MW) }\end{array}$ & $\begin{array}{l}\text { Supply Chain } \\
\text { Investment } \\
\text { (Local Content) }\end{array}$ & $\begin{array}{l}\text { Construction } \\
\text { Cost } \$ / \mathrm{kW})\end{array}$ \\
\hline Low & $370 / 3,200$ & $23 \% / 42 \%$ & $\$ 5,840 / \$ 5,460$ \\
\hline Moderate & $1,910 / 7,830$ & $29 \% / 69 \%$ & $\$ 5,600 / \$ 4,830$ \\
\hline High & $4,100 / 16,280$ & $39 \% / 79 \%$ & $\$ 5,360 / \$ 4,230$ \\
\hline
\end{tabular}

Table 2, shows further detail about local content assumptions for major construction expenditures. Only 2030 values are shown. All scenarios assume that all onsite operations and maintenance (O\&M) staff will be residents of the Mid-Atlantic region by 2030 .

Table 2. 2030 Local Content of Select Expenditures

\begin{tabular}{|l|r|r|r|c|}
$\begin{array}{c}\text { Deployment } \\
\text { Scenario }\end{array}$ & $\begin{array}{c}\text { Blades and } \\
\text { Towers }\end{array}$ & $\begin{array}{c}\text { Nacelles } \\
\text { and } \\
\text { Drivetrains }\end{array}$ & $\begin{array}{c}\text { Erection } \\
\text { Installation } \\
\text { Services }\end{array}$ & $\begin{array}{c}\text { Converter } \\
\text { and } \\
\text { Substation }\end{array}$ \\
\hline Low & $71 \%$ & $66 \%$ & $60 \%$ & $20 \%$ \\
\hline Moderate & $95 \%$ & $95 \%$ & $85 \%$ & $71 \%$ \\
\hline High & $95 \%$ & $100 \%$ & $100 \%$ & $87 \%$ \\
\hline
\end{tabular}

The economic impact of a scenario is dependent on the level of development and portion of expenditures made within the Mid-Atlantic region. In the moderate scenario, development is estimated to support approximately 6,050 total FTE jobs in 2020 and an average of approximately 13,430 annually through 2030 . The distribution of jobs supported by offshore wind deployment changes over time under this scenario. In $2020,22 \%$ of jobs are onsite; by 2030 this decreases to $19 \%$. Conversely, the share of jobs comprised by local revenue and supply chain jobs increases from $40 \%$ in 2020 to $43 \%$ in 2030 . This reflects increased regional investments in an offshore wind supply chain (Table 3 and Figure 1).

Jobs supported by offshore wind are well compensated, with average annual earnings (including employer provided benefits such as retirement and health care contributions) of $\$ 141,000$ annually for onsite workers. Supply chain job holders are estimated to earn approximately $\$ 78,000$, and earnings from induced jobs are approximately $\$ 57,000$.
Table 3. Jobs Supported by the Moderate Scenario

\begin{tabular}{|c|c|c|}
\hline & $\begin{array}{r}\text { Jobs (FTE) } \\
2020\end{array}$ & $\begin{array}{r}\text { Jobs (FTE) } \\
2030\end{array}$ \\
\hline \multicolumn{3}{|l|}{ Construction } \\
\hline $\begin{array}{l}\text { Project Development and } \\
\text { Onsite Impacts }\end{array}$ & 1,320 & 3,520 \\
\hline $\begin{array}{l}\text { Construction and } \\
\text { Interconnection Labor }\end{array}$ & 1,040 & 3,120 \\
\hline Construction-Related Services & 280 & 400 \\
\hline Turbine and Supply Chain Impacts & 2,440 & 7,920 \\
\hline Induced Impacts & 2,290 & 6,890 \\
\hline Total Construction Impacts & 6,050 & 18,330 \\
\hline \multicolumn{3}{|l|}{ Operations and Maintenance } \\
\hline Onsite Labor Impacts & 170 & 620 \\
\hline $\begin{array}{l}\text { Local Revenue and Supply Chain } \\
\text { Impacts }\end{array}$ & 1,330 & 4,920 \\
\hline Induced Impacts & 830 & 3,080 \\
\hline Total O\&M Impacts & 2,330 & 8,610 \\
\hline
\end{tabular}

Totals may not sum due to rounding.

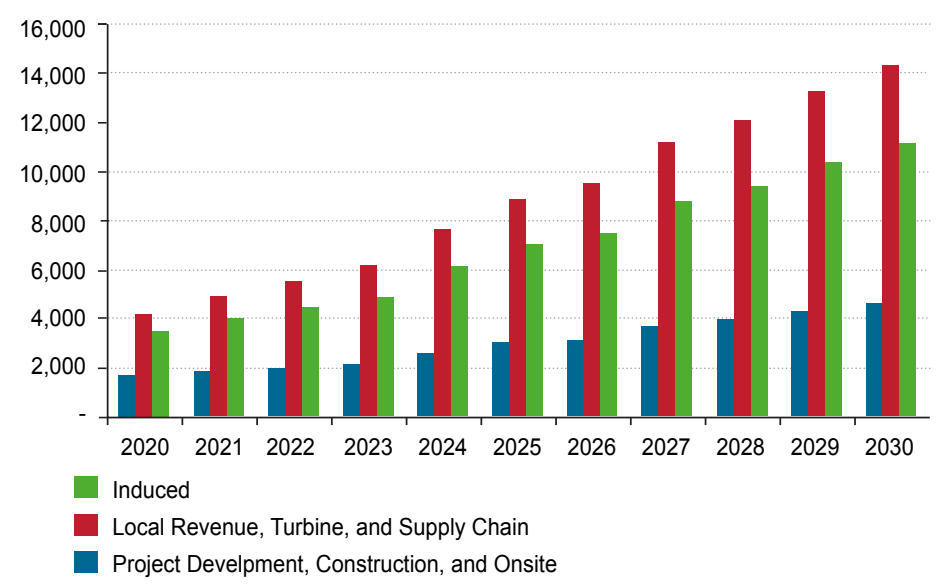

Figure 1. Estimated number of construction and O\&M jobs supported by offshore wind deployment from 2020 to 2030 (moderate scenario)

For more information on DOE offshore wind work, please visit Offshore Wind Market Acceleration Projects at www.eere.energy.gov/wind/offshore_market_acceleration.html. Renewable Energy
For more information, visit: wind.energy.gov 